\title{
Når etterlatte ved selvmord møter presse
}

\author{
Ved Terese Grøm og Henning Herrestad
}

\begin{abstract}
Det er to viktige formål med offentlig formidling av historier og synspunkter fra etterlatte ved selvmord. Det ene formålet er at personlige historier fra etterlatte tilfører opplysningsarbeidet om selvmord en ekstra dimensjon. Ingen kan bedre enn dem som har mistet noen de er glade i ved selvmord, fortelle om menneskene og historiene bak selvmordstallene - både om dem som tok sitt liv og dem som sitter igjen.
\end{abstract}

Det gir oss en unik innsikt i hvilke konsekvenser et selvmord kan få, og det gir statistikk og selvmordstall et innhold vi kan relatere oss til. Motivasjonen for mange av LEVEs medlemmer som intervjues i media, er også ønsket om å redusere antall selvmord. Det kan gi "mening i det meningsløse".

Det andre formålet med formidling av etterlattes perspektiv, er å få frem deres beskrivelser av selvopplevde erfaringer og reaksjoner etter et selvmord.

\section{ABSTRACT \\ Formidling av etterlattes erfaring i media er en viktig del av allmenn folkeopplysning om selvmord. Formålet med denne artikke- len er å gi konkrete råd for etterlatte i møte med pressen, for god åpenhet om selvmord. Hovedpunkter: Du kan selv legge premisser for intervjuet. Få oversikt over sakens vinkling og budskap. Avtal gjen- nomlesing- og korrigeringsmuligheter. Unngå omtale av selvmordsmetode og sted. Hold deg til ditt budskap.}

An important aspect of general education on suicide is the suicide survivors' voice in the media. The aim of this article is to give the survivors advice concerning meetings with the press, to ensure that information communicated in interviews serves its educational purpose. The main issues are: Influence the premises for the interview. Establish the outlines of the press article's angle and message. Make an agreement regarding opportunity to read and correct. Avoid information about method and place of suicide. Stick with your message.
De har kjent smerten på kroppen, de vet hva de snakker om. Vi vet at det appellerer til tanker og følelser hos lesere, lyttere og seere som har opplevd det samme. Det å høre andres erfaring kan gi god bekreftelse på at ens egne taps- og sorgreaksjoner etter et selvmord er normale. Det betyr at man ikke er alene om å ha disse vonde følelsene og tankene. Man er heller ikke alene om å streve med spørsmål man aldri får svar på. Når i tillegg mennesker som selv har mistet noen ved selvmord, kan si at livet kan bli godt igjen, fremstår håp som et troverdig budskap. I et slikt perspektiv har åpenhet om selvmord en helende funksjon for dem som sitter igjen. Vi tror det også har vært med på å redusere tabuer og skam rundt selvmord. Men all åpenhet om selvmord er ikke nødvendigvis god åpenhet. Ikke minst gjelder det når historier om avdøde skal fortelles. Vi vet for eksempel at detaljerte beskrivelser i media av selvmordsmetode eller stedet for selvmordet, kan øke faren for imiterende selvmordsatferd. Å gi slike opplysninger er derfor uheldig når et formål med åpenhet er å redusere antall selvmord. Det er også viktig å ta hensyn til avdødes ettermæle når man velger å fortelle om selvmord. Det kan være personlige detaljer om, eller beskrivelser av, personen som verken er nødvendige eller relevante for saken. I stedet oppfordres etterlatte til å fokusere på opplysninger, tanker og observasjoner som kan hjelpe oss alle til å forstå mer om adferd hos selvmordsnære, og om hva som er god ivaretakelse av etterlatte. Søkte for eksempel personen hjelp før han/hun tok sitt liv? Snakket han eller hun om sine selvmordstanker eller kom selvmordet som "lyn fra klar himmel"?
Og da selvmordet skjedde; hva slags akutt hjelp fikk man - eller skulle man hatt? Hva slags oppfølging fungerte eller fungerte ikke? Hvordan kan livet leves videre? Slike observasjoner og betraktninger kan gi et innblikk i hvordan vi på best mulig måte kan forholde oss til mennesker og familier som har opplevd selvmord.

Refleksjoner i etterkant kan også bidra i arbeidet med å finne frem til god intervensjon og ivaretakelse når livet butter imot og den psykiske og mentale helsen svikter - både hos den selvmordsnære og hos den som blir igjen. Likeså kan det bidra til å forsterke påtrykk for å innføre konkrete forebyggingstiltak som vi vet har god effekt, slik som å sikre broer. Men hvordan legge til rette for et godt og hensiktsmessig møte mellom etterlatte og pressen?

\section{Gode forutsetninger for et godt intervju}

I medienes Vær varsom-plakat § 4.9 (WP, 2013), understrekes det at man skal være varsom ved omtale av selvmord, selvmordsforsøk og beskrivelse av metoder, og at man skal unngå å skrive noe som ikke er nødvendig for det allmenne informasjonsbehov. Det siste kan dreie seg om å unngå opplysninger som tilhører den private sfære, slik som informasjon fra en persons medisinske journal etter hans eller hennes død. Siden det er journalistens ansvar å følge opp disse etiske føringene, er det lett å tenke at forutsetningene for en god og trygg intervjusituasjon allerede er lagt. Men slik trenger det ikke å være. Journalister er mennesker som alle oss andre, og de kan tilsiktet eller utilsiktet spørre om informasjon som allmennheten ikke trenger å vite noe om, slik som private detaljer om den avdøde. 
Og når journalisten spør om noe, er det lett å føle seg forpliktet til å svare. Det kan derfor være godt å vite i forkant av et intervju at man ikke behøver svare på alt, og at man selv kan henvise til journalistens etiske føringer hvis man opplever intervjusituasjonen og spørsmål ubehagelig. Selv om Vær varsom-plakaten er til for å trekke slike grenser, kan likevel gråsoner mellom nødvendig og unødvendig informasjon lett oppstå. Journalisters fortolkning av paragrafen kan også variere, og spørsmålene kan bli deretter. Det er også viktig å anerkjenne opplevelsen av fortrolighet og nærhet som kan oppstå mellom intervjuobjekt og journalist. Personlige historier kan være vonde, nære og følelsesladete, også der den etterlatte har hendelsen på avstand, og det er ikke uvanlig at journalisten berøres $i$ møte både med historien og den som forteller. På den ene siden kan det skape en god, tillitsfull og respektfull atmosfære som gagner historieformidlingen som blir til mellom intervjuobjekt og journalist. På den annen side kan følelsen av ufarlighet og fortrolighet øke risikoen for at enkelte private opplysninger oppgis, som den etterlatte egentlig ikke ønsket å dele, eller senere angrer på at hun eller han ga. Slikt kan skje, spesielt når man til daglig ikke forholder seg til medieverdens koder. Men det betyr ikke at man skal si nei takk til intervju av den grunn. Som vi har vist er de etterlattes perspektiv et viktig element når selvmord snakkes om i offentligheten. Det handler heller ikke om at journalisten skal møtes med grunnleggende skepsis. Journalister er stort sett opptatt av å gjøre en god jobb som de fleste andre. LEVE har fremfor alt positive erfaringer med pressen. Det som er viktig er at den etterlatte føler seg komfortabel i intervjusituasjonen, slik at opplevelsen blir god og at det endelige resultatet preges av god og hensiktsmessig åpenhet om selvmord. En slik opplevelse oppnår man gjerne når man selv, som intervjuobjekt, kan legge noen premisser for intervjuet.

\section{Møtet mellom selvmords- etterlatte og presse}

\section{Vær Varsom-plakaten (2013)}

I Vær Varsom-plakaten, er $\S 4.9$ spesielt viktig. Den lyder slik:

- Vær varsom ved omtale av selvmord og selvmordsforsøk.

- Unngå omtale som ikke er nødvendig for å oppfylle allmenne informasjonsbehov.

- Unngå beskrivelse av metode eller andre forhold som kan bidra til å utløse flere selvmordhandlinger.

Andre paragrafer i Vær Varsomplakaten som kan være verdt å nevne her:

3.9. Opptre hensynsfullt i den journalistiske arbeidsprosessen. Vis særlig hensyn overfor personer som ikke kan ventes å være klar over virkningen av sine uttalelser.

4.5. Unngå forhåndsdømming i kriminal- og rettsreportasje. Gjør det klart at skyldspørsmålet for en mistenkt, anmeldt, siktet eller tiltalt først er avgjort ved rettskraftig dom.

4.13. Feilaktige opplysninger skal rettes og eventuelt beklages snarest mulig.

4.14. De som utsettes for sterke beskyldninger skal såvidt mulig ha adgang til samtidig imøtegåelse av faktiske opplysninger.

4.15. De som er blitt utsatt for angrep skal snarest mulig få adgang til tilsvar, med mindre angrep og kritikk inngår som ledd i en løpende meningsutveksling.

I tillegg henvises det til Veileder for omtale av selvmord, utarbeidet av Reidun Kjellaug Nybø på oppdrag av Norsk Presseforbund (Nybø, 2005).

Intervjuobjektet kan selv ha god nytte av å vite litt om råd om selvmordsomtale rettet mot pressen. Én kilde her er som nevnt medienes egne etiske veileder, Vær Varsom-plakaten (WP). En annen kilde er medieråd fra Verdens Helseorganisasjon (WHO).

\section{Vær Varsom plakaten}

Vær Varsom-plakatens § 4.9 (WP, 2013) er den viktigste etiske retningslinjen. Den har vi allerede sagt noe om. Men også andre deler av Vær Varsom-plakaten spiller en rolle i intervjuer som dreier seg om selvmord. Spesielt gjelder det oppfordringen om å vise hensyn til personer som kanskje ikke er helt innforstått med virkningen av sine uttalelser (WP, 2013, § 3.9). Siden de fleste av oss har liten eller ingen erfaring med å bli intervjuet av pressen, kan det være vanskelig å forestille seg hvordan ens utsagn oppfattes når de fremheves som enkeltsitater. Ting som sies i en samtale mellom to mennesker, kan fremstå annerledes i en skriftlig oppsummering preget av journalistens vinkling, eller i en redigert og klippet radioeller tv-sending. Det kan også være en utfordring i øyeblikket å skille mellom hva man selv synes er greit å si, og hva som fremstår for privat i det offentlige rom. Spesielt kan dette skje når selvmordet fortsatt er nært og følelser er lite bearbeidet, kanskje i kombinasjon med god kontakt med journalisten. Her er det til syvende og sist journalistens ansvar å sørge for at informasjon som formidles ut er informasjon som kan stå seg i det offentlige rom. Derfor heter det at journalistens oppgave er "å beskytte intervjuobjektet mot seg selv". I det ligger altså ikke at etterlatte ved selvmord, eller andre som har opplevd traumatiske ting, ikke er i stand til å passe på seg selv. Men det innebærer at uttalelser kan gi virkninger som intervjuobjektet ikke alltid er i en posisjon til å vurdere mens det samtales. Et annet element journalisten har et spesielt ansvar for, er at eventuelle beskyldninger som rettes mot personer eller instanser, skal kunne bli imøtegått av den anklagede (WP, 2013, § 4.14). For eksempel er det etterlatte ved selvmord som bærer nag til helsevesenet, ofte på grunn av det de oppfatter som dårlig behandling ved psykiatriske sykehus eller fravær av imøtekommenhet ved legevakt. 
Hvis slike anklager kommer under intervjuet, og journalisten vurderer at dette bør tas med som en del av sakens helhet, skal journalisten sørge for at anklagede får mulighet til å kunne imøtegå faktaopplysninger. Det er imidlertid ikke slik at helsepersonell alltid har en faktisk mulighet til å kunne kommentere saken, på grunn av taushetsplikt eller andre arbeidsmessige årsaker, men de skal uansett få en henvendelse. Det er god presseskikk, og dette bør også intervjuobjektet være klar over. Ingen beskyldninger skal få stå uimotsagt, så sant det er mulig.

\section{Råd fra Verdens Helseorganisasjon}

\section{WHO (2008) om god åpen-} het i media:

- Benytt sjansen til å gi befolkningen kunnskap om selvmord.

- Unngå ord og uttrykk som gjør selvmord til en sensasjon, som alminneliggjør selvmord eller framstiller selvmord som en løsning på problemer.

- Unngå iøynefallende plassering og unødig gjentakelse av selvmordsomtaler.

- Unngå å beskrive selvmordsmetoden.

- Unngå å beskrive stedet der selvmordet eller selvmordsforsøket skjedde.

- Vær bevisst på ordvalget i overskrifter.

- Vis forsiktighet ved bruk av bilder og video.

- Vær spesielt varsom ved omtale av kjendisselvmord.

- Vis hensyn overfor de etterlatte.

- Opplys om hvor det er hjelp å få.

- Vær klar over at også mediefolk kan bli påvirket av selvmordsomtaler.

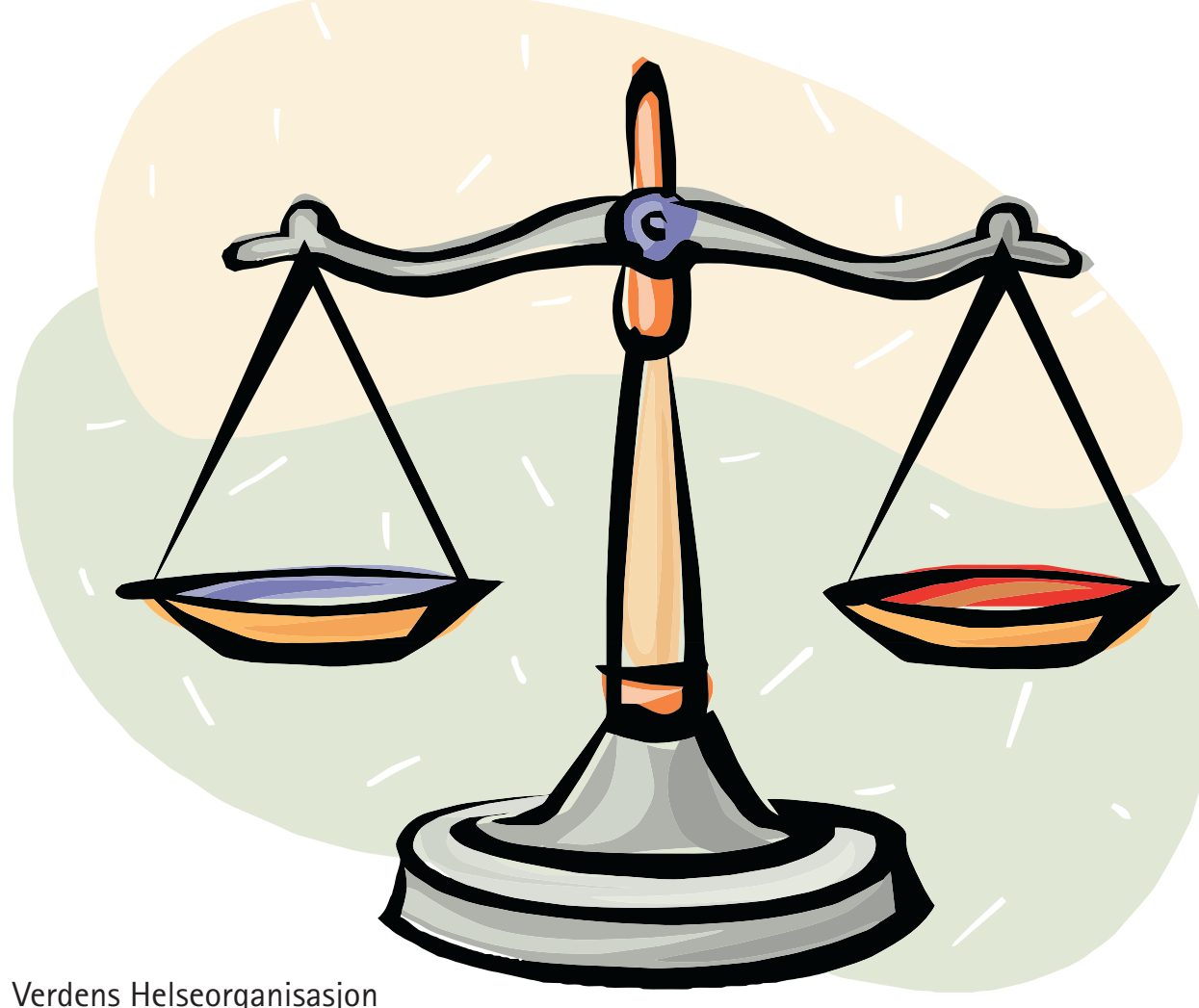

ga i 2008 ut sine råd for god åpenhet om selvmord i media. I likhet med Vær Varsom-plakaten understrekes også her varsomhet ved beskrivelse av metode og sted, både gjennom ord, stillbilder og levende bilder. I tillegg oppfordrer WHO den enkelte til å reflektere over sitt ordvalg når man snakker om selvmord, slik at ikke selvmord fremstilles som en akseptert løsning på problemer i livet. Det bør også intervjuobjektet være litt oppmerksom på, samtidig som vi skal anerkjenne at det å akseptere et selvmord kan ha ulik betydning for mennesker som mister noen ved selvmord. Det er for eksempel forskjell på det å akseptere at selvmordet har skjedd, og det å akseptere at selvmordet var en god løsning eller den eneste løsning. Det å akseptere at en person tok sitt liv, er først og fremst en erkjennelse av hendelsen i seg selv. Selvmordet har faktisk funnet sted, det er hva man her tar innover seg. En slik erkjennelse kan være til hjelp for den etterlatte. Mange finner også fred i å akseptere at selvmordet var personens valg, eller gjennom å akseptere at selvmordet var den løsningen personen var i stand til å se i sin smerte.
Dette er imidlertid ikke det samme som å si at selvmordet var den eneste løsningen.

Imidlertid, hvis aksept formidles på en slik måte at den døde fremstår som en individuell og selvstendig "helt", der hun "fulgte sin vei og gjorde det hun måtte gjøre", så er det fare for at selvmordet kan fremstilles som den eneste - og riktige - løsningen. Det er hva WHO ønsker å unngå. Ingen er på andres vegne berettiget til å hevde hvilket liv som er verdt å leve eller ikke, og ingen har løsninger som kan garantere et godt liv. Men det WHO (2008) ønsker å si med sitt råd er at ugjennomtenkt ordvalg om et selvmord kan overskygge det faktum at det faktisk finnes andre løsninger som er verdt å prøve. Det finnes hjelp. Det er mange mennesker som i dag er glade for at de ga andre løsninger en sjanse. Derfor er det så viktig at både journalist og intervjuobjekt er bevisste på hvordan deres ordvalg kan påvirke andres tankegods og beslutninger. "Hadde han bare snakket med oss om hvor vanskelig han faktisk hadde det", sier noen etterlatte, "så skulle vi funnet en løsning sammen!" 
Et slikt budskap er ingen motsetning til at man finner fred med at den døde ikke lenger lever et liv i smerte. Det er en av grunnene til at selvmordsetterlattes perspektiv har stor betydning i selvmordsforebyggende arbeid.

\section{Konkrete råd til den etterlatte når journalisten tar kontakt}

\section{Når journalisten ringer}

- Hvem ringer og fra hvilket medium?

- Hva vil journalisten? Hvorfor blir akkurat du kontaktet?

- Hvilket mandat/hvilken grunn har du til å uttale deg?

- Ønsker journalisten sitat eller fakta til bakgrunnsstoff, eller ønsker han/ hun din historie?

- Hvis din historie; hva er journalistens vinkling og budskap? Hva ønsker han/hun å få fram? Hva tjener det å få publisitet? Gagner det saken å få offentlig debatt?

- Vil du bli forelagt hele artikkelen eller bare egne sitater?

Vil det skje på mail eller telefon? Det anbefales å be om oversending av intervju på mail, slik at du kan lese igjennom i ro og fred.

- Det er selvfølgelig ingenting i veien for å ta intervjuet der og da. Men, om du opplever du ikke har et klart budskap, eller du vil snakke med andre $f ø r$ du uttaler deg/intervjues, be alltid om å få ringe tilbake! Når er deadline?

I de fleste tilfeller er det slik at journalisten tar kontakt, og ofte kan oppringingen komme uanmeldt og uforberedt. Det som er fint å vite er at man ikke trenger å gi intervjuet i denne første henvendelsen.
I stedet kan man benytte denne første henvendelsen fra journalisten til å stille ham/henne noen spørsmål. For eksempel er det en god start å få en oversikt over hva som er journalistens ønske med saken, hva han eller hun vil ha frem og hva som forventes av deg i akkurat denne sammenhengen. Føler du at dette er en sak hvor du kan bidra til en god og offentlig debatt? Kan din rolle gi artikkelen eller innslaget et bredere perspektiv? Klargjør eget hovedbudskap så langt det er mulig før intervjuet, og be gjerne om å få oversendt spørsmål på forhånd, slik at du har mulighet til å diskutere disse med andre før intervjuet. Det er bedre å bruke en intervjusituasjon til å få sagt noe man selv mener bør frem, enn å være overlatt til hva journalisten tror er viktig.

En annen viktig ting å etablere er muligheten til å kvalitetssikre intervjuet før det publiseres. Alle slike avtaler bør gjøres før intervjuet. Når intervjuet er gjort, kan man ønsker å se sine sitater og opplysnin-
med ønsker.
ger i en sammenheng. Etter intervjuet
kan som sagt et slikt ønske være
for sent.

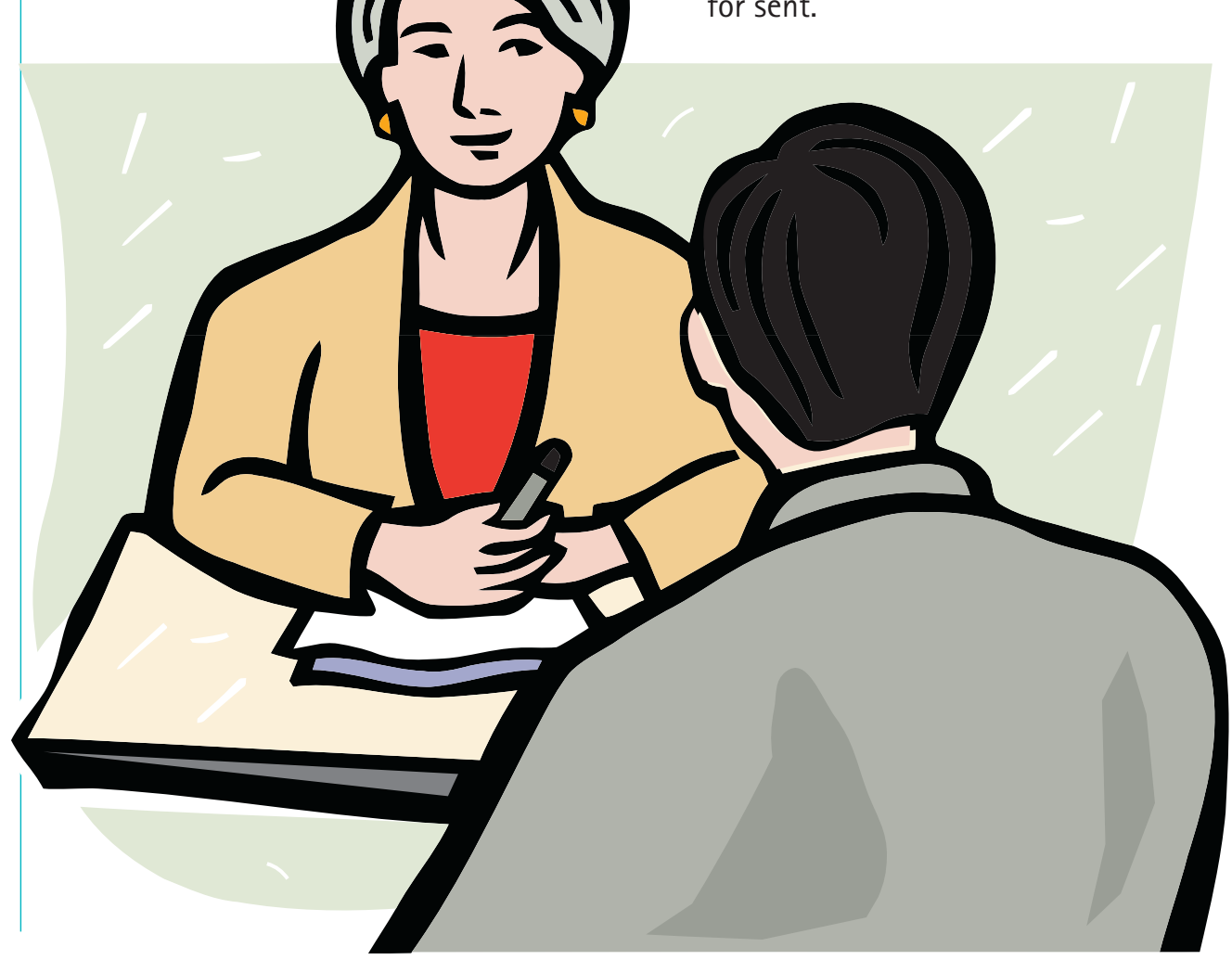

En forhåndsavtale kan også gi en god følelse av å ha kontroll over hva som til slutt vil publiseres, som igjen legger til rette for en trygg og god intervjuopplevelse. En slik kvalitetssikring er naturlig nok enklest å gjennomføre ved avisintervjuer. Her anbefales det å be om at resultatet av intervjuet skal sendes over på mail, slik at man uforstyrret kan lese igjennom og se om opplysninger man har gitt er oppfattet korrekt av journalisten, og om sitater stemmer med det man ønsket å formidle.

Her må man selv passe på å be om mulighet for utvidet kontrollsjekk av intervjuet, om man ønsker det. Det er for eksempel ingen selvfølge at intervjuobjektet får oversendt hele saken i sin helhet, spesielt i saker der man blir kontaktet kun for å gi innspill.

Det er først og fremst egne sitater man har krav på å kunne korrigere. Derfor er det viktig at man på forhånd ber spesifikt om å få se artikkelen i sin helhet, hvis man ønsker å se sine sitater og opplysninger i en sammenheng. Etter intervjuet for sent. 
LEVEs erfaring er imidlertid at de fleste journalister viser stor raushet i slike forhåndsavtaler når det gjelder etterlatte ved selvmord, nettopp fordi journalisten selv er interessert $\mathrm{i}$ at tematikken formidles på en god måte.

Det kan også nevnes at LEVEs sekretariat med jevne mellomrom mottar mailer fra medlemmer som har blitt intervjuet og som ønsker bekreftelse på at opplysninger og sitater de har gitt i en artikkel, er ok.

En slik oversending av artikkel/sitater til LEVE har de da også avtalt med journalisten før intervjuet. Det er derfor viktig å poengtere at det er lov å spørre, uten at man blir garantert slike muligheter. Dermed vil det være opp til den etterlatte selv om han eller hun ønsker å gjennomføre intervjuet med den forhåndsavtalen om kvalitetssikring (eller om andre faktorer ved intervjuet) som til slutt foreligger. Ved radio- og tv-intervjuer er et slikt ettersyn noe vanskeligere, men man kan be om at visse ting blir redigert bort $\mathrm{i}$ etterkant av et intervjuopptak, hvis man ikke er helt fornøyd med hva som ble sagt eller hvordan det ble sagt. Eller man kan avbryte under intervjuet og be om å få svare på nytt.

Intervjuer som går direkte på lufta har ingen slike redigeringsmuligheter. Ved denne type intervjuer er det derfor spesielt viktig at journalist og den etterlatte er enige på forhånd om hvilke spørsmål som vil bli stilt, slik at intervjuobjektet kan forberede seg på det.

Intervjuobjekter blir gjerne ringt opp en stund før direktesendinger, slik at vedkommende både kan tenke seg om og ringe tilbake, eller si nei der og da. Hvis du i løpet av en første samtale med journalisten skulle bestemme deg for å gjennomføre intervjuet der og da uten betenkningstid - om det er for avis, radio eller tv - finnes også noen enkle råd som kan være gode å forholde seg til.

\section{Før og under intervjuet}

Hvis du bestemmer deg for å gjennomføre intervjuet uten betenkningstid, er det også noen spørsmål og råd som kan være gode å forholde seg til før og under intervjuet:

- Kan du for eksempel få spørsmålene på forhånd?

Evt. angivelse av temaområder?

- Hvis det er et TV-/radiointervju; kan dere gå gjennom intervjuet på forhånd? Kan det redigeres i etterhånd? Hvor langt blir innslaget?

- Si alltid det mest vesentlige først!

- jo mer du sier, jo mindre kontroll på hva som kommer med. Unngå småsnakk.

- Jo kortere og mer spissformulert, jo mer direkte sitat.

- Vær rolig. Ikke bli sint.

- Hva er det DU vil oppnå? Hva er DITT budskap? Kan du si det enkelt, rett fram og med vanlige ord?

- Kan du dokumentere påstandene dine?

- Vær oppmerksom på hva du formidler non-verbalt i radio/ TV.

Vi har allerede vært innom det å få vite litt om spørsmålene, hvilke korrigeringsog redigeringsmuligheter som finnes etc. I tillegg kan det være lurt å tenke seg om ved hvert spørsmål man blir stilt underveis i intervjuet, og holde seg rolig, unngå småsnakk og forsøke så godt man kan å holde seg til det budskapet man faktisk ønsker å formidle.
Til slutt minner vi om at god åpenhet om selvmord er en viktig del av den allmenne folkeopplysning om selvmord. Så til deg som velger å bruke media som arena ha en god intervjuopplevelse og takk for ditt bidrag i det viktige selvmordsforebyggende arbeidet.

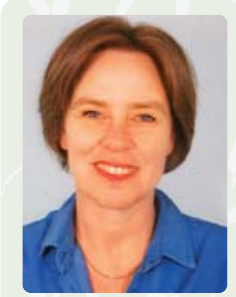

Terese Grøm avslutter sin mastergrad i filosofi ved UiO, mai 2014. Hun vikarierer som organisasjonskonsulent og prosjektleder i LEVE - Landsforeningen for etterlatte ved selvmord. Grøm var informasjonsansvarlig i LEVE fra 2001 til 2009, og er tidligere utdannet innen visuell kommunikasjon, veiledning og journalistikk.

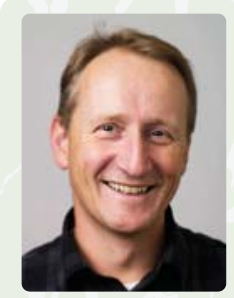

Henning Herrestad er arbeidende styreleder for LEVE - Landsforeningen for etterlatte ved selvmord. Han arbeider også som spesialrådgiver med ansvar for selvmordsforebygging ved Regionalt resssurssenter om vold, traumatisk stress og selvmordsforebygging (RVTS Øst). Han er utdannet dr.philos. i filosofi og gestaltterapeut MNGF.

\section{Litteraturhenvisning}

Nybø, R.K. (2005). Veileder for omtale av selvmord. Norsk Presseforbund. http://presse.no/Saker / Veileder-for-omtale-av-selvmord

Vær varsom-plakaten. (Siste revisjon 01.07.2013). Etiske normer for pressen (trykt presse, radio, fjernsyn og nettpublikasjoner). Norsk Presseforbund. http://presse.no/Etisk-regelverk/VaerVarsom-plakaten

World Health Organization. (2008). "Preventing suicide: a resource for media professionals." International Association for Suicide Prevention (Norsk utgave). http://apps.who.int/iris/bitstream/ 10665/43954/9/9789241597074_nor.pdf 